\title{
CLIENTELISMO E DEMOCRACIA CAPITALISTA: ELEMENTOS PARA UMA ABORDAGEM ALTERNATIVA'
}

\author{
Francisco Pereira de Farias \\ Universidade Federal do Piauí
}

\begin{abstract}
RESUMO
O objetivo central deste artigo é apresentar um conceito da barganha político-eleitoral ("clientelismo") compativel com o de democracia capitalista. O argumento é que o fundamento das práticas clientelistas encontra-se não em uma herança de relações pré-capitalistas, mas, sim, na própria estrutura social capitalista. A cidadania política comporta como uma das alternativas o modelo competitivo análogo ao mercado econômico. O enfoque é ilustrado com o estudo empírico de uma subregião do Nordeste brasileiro.
\end{abstract}

PALAVRAS-CHAVE: clientelismo; democracia capitalista; Nordeste brasileiro.

\section{INTRODUÇÃO}

Uma ampla corrente da Ciência Política guiase pela formulação do problema de uma oposição entre o clientelismo e a democracia. Duas proposições resumem a oposição: i) o clientelismo é a apropriação privada da coisa pública; ii) a barganha do voto representa uma corrupção da democracia. As razões apresentadas para o desvirtuamento da democracia pelo clientelismo normalmente são: a pobreza, a ignorância, a herança de um passado pré-moderno. Acreditase que, com a consolidação da democracia, o clientelismo poderá ser reduzido a um patamar insignificante ${ }^{2}$.

A oposição entre o clientelismo e a democracia está, a nosso ver, assentada numa premissa pouco consistente: uma determinada concepção de democracia, definida com base na sua variante "liberal" (procedimento universalista). Mas o universalismo não esgota todas as possibilidades da democracia no capitalismo. Outros padrões de política são compatíveis com a democracia capitalista: o classismo, o populismo, o corpora-

\footnotetext{
1 Este trabalho representa uma síntese da nossa dissertação de mestrado (FARIAS, 1999), defendida junto ao Instituto de Filosofia e Ciências Humanas da UNICAMP, sob a orientação do Professor Dr. Décio Saes.

2 São representativos dessa perspectiva de análise os trabalhos de Roniger (1994), Lemarchand (1981), Rouquié (1978) e Scott (1971).
}

tivismo. Como procuraremos evidenciar, o clientelismo é também uma das formas políticas intrínsecas a tal tipo de democracia.

Uma análise concreta da realidade social deve partir do princípio de que a perpetuação de uma determinada ordem social requer um modo específico de aparelhamento institucional. Assim, o tipo de democracia adequado à manutenção do capitalismo não pode ser o mesmo daquele necessário à reprodução do socialismo, uma vez que tais sistemas sociais têm regras estruturantes antagônicas. Nesse sentido, podemos falar numa democracia capitalista, ou seja, em um conjunto de procedimentos políticos - sistema do voto, competição partidária, representação parlamentar -, regido pelo princípio da soberania popular, o qual contribui para a manutenção do sistema capitalista. No capitalismo, não é necessário que as instituições políticas sejam diretamente apropriadas pela classe dominante, pois elas possuem uma lógica e uma unidade, determinadas pela estrutura do Estado burguês (indivíduos juridicamente igualados e identificados como agentes da soberania popular), que estabelecem as condições políticas da dominação de classe, à medida que opõem obstáculos à organização autônoma dos dominados. Uma política de esquerda que venha a obter sucesso no interior dessa democracia apenas poderá minimizar os efeitos reprodutivos favoráveis à ordem social dominante. Para alcançar os objetivos socialistas, as forças de esquerda têm que construir um novo tipo de democracia. 
Portanto, há um limite estrutural ao funcionamento da democracia: o seu comprometimento com uma dada ordem social. Esse fato é inclusive consagrado nas constituições dos vários países capitalistas, e se manifesta também na exclusão do partido da revolução social (que propõe o desmantelamento do Estado capitalista) da competição política legal (SAES, 1987, p. 63-64).

Os limites de abrangência (voto feminino, de analfabetos, racial etc.) da democracia capitalista diferem segundo os estágios da luta de classes. Em geral, a burguesia procura estreitar o raio de inclusão das massas populares no processo político, enquanto essas lutam para ampliar a sua participação, uma vez que isso favorece as condições de sua organização política como classe (THERBORN, 1977). Portanto, a luta social determina a variação na abrangência da democracia, o que se expressa nas diferentes legislações partidárias e eleitorais.

A competição partidária peculiar à democracia capitalista, limitada quanto ao seu conteúdo e à sua abrangência, sofre novas restrições no plano do seu funcionamento, pois, embora tal competição esteja oficialmente orientada pelo princípio da universalidade, na prática, em decorrência da estrutura social capitalista, coexiste com vários mecanismos particularísticos de controle do eleitorado, tal como o clientelismo.

\section{A BARGANHA POLÍTICO-ELEITORAL COMO UMA COMPONENTE DA DEMO- CRACIA CAPITALISTA}

Uma expressão característica do clientelismo é o voto mercadoria, ou seja, a relação de barganha, em torno de vantagens materiais, entre o eleitor e o cabo eleitoral (uma espécie de líder local, que cuida dos interesses de seus representados, principalmente junto às "autoridades públicas", fazendo as vezes de, segundo a expressão de Paulo Singer, um "advogado administrativo" da sua comunidade - uma vila, uma favela, um quadro associativo de um clube recreativo etc.). Controlando, em geral, uma centena ou uma dezena de votos, o cabo eleitoral os vende ao "político de clientela", que "não passa de um cabo eleitoral suficientemente poderoso" (SINGER, 1965, p. 77).

A condição sócio-econômica para a proliferação do voto de barganha é a predominância de relações de produção capitalistas, basicamente a conversão da força de trabalho, através do assa- lariamento, em mercadoria - o que pressupõe a existência do trabalhador livre, isto é, despojado dos meios de subsistência, em particular do vínculo à terra. Trata-se do trabalhador que abandona a condição da dependência pessoal (o colonato, a moradia) frente ao dono de terras, para se submeter à dependência impessoal (o assalariamento) relativa às coisas.

A dependência com respeito às coisas, ou seja, à lei da mercadoria, pode ser vista sob um duplo aspecto. De um lado, ela indica o poder econômico do capitalista, proprietário dos meios de subsistência, sobre o trabalhador, vendedor da força de trabalho. De outro lado, ela expressa a constituição do trabalhador em sujeito de interesse, que, na relação política, pode converter o voto em um instrumento de barganha por vantagens materiais, isto é, em um recurso salarial ${ }^{3}$.

A política democrática liberal, dirigindo as suas mensagens às classes sociais configuradas como eleitores, isto é, indivíduos isolados (e normalmente em posição defensiva), abre espaço para a ação do cabo eleitoral, que propõe ao eleitor um cálculo utilitário: aceitar um benefício imediato e certo em troca do voto, ao invés de apostar em vantagens mais amplas porém incertas ${ }^{4}$. A cidadania pode assumir uma forma concreta através do clientelismo, porque o sentimento da liberdade no exercício do direito político - o voto livre comporta a alternativa de negociá-lo.

Uma interpretação recorrente do clientelismo tende a identificar como o seu fundamento não a estrutura social capitalista, mas a herança de um passado pré-capitalista. Assim, nos países do "Terceiro Mundo", a herança colonial seria o fator determinante da presença do clientelismo na democracia moderna. Para R. Lemarchand, por exemplo, "é primordialmente onde a mudança social tem estagnado substancialmente por trás da mo-

\footnotetext{
3 O argumento é análogo ao estabelecido por Saes (1994, p. 90) sobre as dimensões econômica e ideológica da dependência pessoal.

4 Existe uma dificuldade, ressaltada por Greco: o cliente, devido à sua baixa disponibilidade de informações, poderia fazer uma previsão adequada de custos e benefícios na fase inicial da relação clientelista? De acordo com o autor, o analista deveria impor-se a cláusula de que o cabo eleitoral estaria "em condições de influenciar o cálculo de conveniência do cliente e, em última análise, de fundar a necessidade" (GRECO, 1972, p. 185).
} 
dernização política que as formas de dependência clientelista têm tido mais resistência" (apud RONIGER, 1994, p. 215).

Duas objeções podem ser indicadas à interpretação do clientelismo como fenômeno "prémoderno" (pré-capitalista). Primeiro, o argumento parte da premissa de que a população "marginalizada" (sem emprego estável) e pobre das periferias urbanas - alvo de práticas clientelistas - seja uma herança do passado colonial desses países. Porém outros estudos, como o de Oliveira (1972), mostram que o subemprego urbano é antes de mais nada um produto do tipo de capitalismo gestado nessas sociedades.

Segundo, a persistência da pobreza pré-capitalista no campo gera, na verdade, as condições de um outro tipo de fenômeno político - o coronelismo. Esse define-se pela manifestação de fidelidade pessoal do eleitor a um chefe político - o coronel (LEAL, 1986, p. 25). Como tal, o voto não é redutível nem ao mecanismo da troca mercantil, nem às formas de coerção física. Ao contrário, a legitimidade do ato eleitoral como uma obrigação moral se concretiza na doação pura e simples do voto ao candidato do coronel.

Como mostram os trabalhos mais abalizados sobre o coronelismo (idem; SAES, 1994), a condição sócio-econômica da prática coronelista é a existência, no campo, de uma estrutura précapitalista, em que as relações de produção se expressam como relações de dominação e dependência pessoal. A relação pessoal de dominação e dependência, presente em estruturas econômicas pré-capitalistas como a parceria ou o arrendamento, implica a apropriação do sobretrabalho sob a forma extra-econômica de uma contraprestação pessoal do trabalhador ao proprietário pela cessão de uso da terra ${ }^{5}$.

A forma da relação política encontra-se implícita na dominação e dependência pessoal: "a dependência pessoal, cujo fundamento é a cessão da posse da terra, exprime-se ideologicamente como

\footnotetext{
5 Manuel C. de Andrade destacou a natureza do vínculo presente na prática do cambão, na qual o foreiro se obriga a fornecer ao dono da terra um dia semanal de trabalho gratuito: "É uma obrigação pessoal, o que leva em certas regiões ao costume de não se permitir que o foreiro pague a outro para que ele execute a tarefa, tendo de prestá-la pessoalmente, como uma homenagem ao proprietário" (ANDRADE, 1980, p. 205).
}

obrigação subjetiva de lealdade para com o senhor da terra, ou, num nível mais diretamente político, como fidelidade ao chefe político local" (SAES, 1994, p. 90).

Portanto, nas sociedades agrárias onde vigem relações de produção pré-capitalistas, como em boa parte do campo brasileiro até período recente, o par eleitor e coronel tem por base a relação entre o trabalhador rural e o grande proprietário de terras. Victor N. Leal, em sua clássica definição do coronelismo, destacou esse ponto: "Não é possível compreender o fenômeno sem referência à nossa estrutura agrária" (LEAL, 1986, p. 20), pois a força eleitoral do coronel é "natural coroamento de sua privilegiada situação econômica e social de dono de terras" (idem, p. 23) ${ }^{6}$.

Assim, a abordagem do clientelismo como um fenômeno "pré-moderno", tendendo a confundilo com o coronelismo ${ }^{7}$, desconsidera o fato de ser aquele uma das formas características da democracia capitalista, e não uma condição externa a essa ("ambiental"). A plausibilidade de tal afirmativa aumenta quando consideramos que o clientelismo persiste, embora de uma maneira mais sofisticada, mesmo nas sociedades capitalistas mais desenvolvidas (THEOBALD, 1992) .

\footnotetext{
6 Dado o contexto em que Victor Leal escreve seu trabalho (década de 1940), fica subentendido que ele se refere ao latifúndio pré-capitalista ("fazenda") e não ao latifúndio capitalista ("empresa rural"). Essa ressalva traz problemas ao conceito de "neocoronelismo", que se baseia no argumento de que a estrutura fundiária no Brasil, particularmente na região Nordeste, continua concentrada. É necessário se observar o que se passa nas relações sociais de trabalho: mais que a estrutura fundiária (concentração da terra), é preciso analisar a estrutura agrária (propriedade e relações de produção).
}

7 O coronelismo é, na realidade, um fenômeno híbrido: em parte pré-burguês (manifestação, no plano político, dos laços de servilismo do produtor para com o dono dos meios de produção), em parte burguês (pressupõe a extensão do direito político a todos os membros da coletividade).

8 No prefácio ao livro de NUNES (1997, p. 12), Bresser Pereira afirma que, no período do nacional-desenvolvimentismo brasileiro, "o clientelismo era ao mesmo tempo o instrumento político por excelência para garantir a implementação de políticas modernas, o seu maior adversário". Mas a contradição é apenas aparente, porque o clientelismo não está fora do círculo das políticas "modernas" (burguesas). O problema surge quando se concebe o clientelismo como prática oposta à lógica do mercado econômico. Certamente uma questão a ser aprofundada refere-se a quais são as "arenas políticas" 
A prática da compra e venda do voto, quando confrontada com uma visão da democracia pautada no princípio universalista, é considerada corrupção eleitoral. No entanto, como P. Singer esclarece, no sistema capitalista, "tudo o que tem equivalência econômica tende a transformar-se em mercadoria [...]. Os cargos eletivos são cada vez mais suscetíveis de proporcionar rendimento econômico. Isto faz com que, de modo crescente, o voto se torne mercadoria. $\mathrm{O}$ processo corruptor é uma conseqüência inevitável do próprio capitalismo" (SINGER, 1965, p. 80).

O grande capital está em condições de manter uma política clientelista, uma vez que dispõe de dinheiro que pode ser convertido em votos, diferentemente da pequena burguesia, que não tem meios para financiar políticos de clientela e mantêlos a seu serviço. Além disso, ocupado em dirigir a sua empresa, o pequeno capitalista não tem muito tempo para a política. O grande capitalista normalmente participa da vida política, pois, como a administração das empresas em que possui ações o ocupa pouco (já que se dedica a tarefas de comando geral), dispõe de bastante tempo para investir na política. Além do mais, os seus interesses dependem, em grande parte, de medidas governamentais (créditos de bancos oficiais, política cambial, subsídios etc.), o que faz que sua atividade normal seja desenvolvida em contato freqüente com políticos profissionais, de cuja influência necessita para obter favores do governo. Assim, normalmente, o grande capitalista faz valer o seu poder econômico em termos políticos (idem, p. 104-105).

Tendo consciência de que as medidas tomadas pelo governo favorecem os interesses de alguns e não contemplam os de outros, os capitalistas se organizam para ter influência política. Eles tendem a encarar a despesa em política "como um investimento que deve, no devido tempo, proporcionar lucro". E logo se convencem de que é "muito mais eficiente participar do financiamento da eleição de algumas centenas de deputados federais do que gastar o equivalente na eleição de um ou dois representantes diretos" (idem, p. 76). O deputado federal é, assim, um dos elos superiores de uma rede de clientela, que passa por níveis intermediários até

privilegiadas do clientelismo burguês no Brasil e como se relacionam a outros padrões de política burguesa. chegar ao cabo eleitoral e sua clientela local. Portanto, a política de clientela torna-se, em última análise, uma das formas de inserção dos capitalistas no campo da ação política.

Uma outra interpretação do clientelismo eleitoral aponta como pressuposto para a sua reprodução a condição de pobreza das classes trabalhadoras. No entanto, é preciso atentar para o fato de que o trabalhador da grande propriedade rural précapitalista, embora vivendo em condições ainda mais precárias - sem acesso a água encanada, luz elétrica, posto médico etc. - do que as de um trabalhador habitante na periferia urbana, nem por isso faz do seu voto um bem de troca. Ao contrário, em razão de sua fidelidade ao patrão-coronel, ele simplesmente doa o voto. É o chamado "cabresto". O enquadramento social do latifúndio précapitalista impede, portanto, que o fenômeno da carência induza o trabalhador, no plano político, a um comportamento clientelístico.

Um dos problemas em se considerar a pobreza como o fator explicativo do clientelismo está em que, nesse procedimento, abstrai-se o tipo das relações sociais sob as quais se reproduz a situação de miséria. Uma explicação mais consistente do voto de barganha, portanto, decorre da consideração da estrutura social capitalista. Se no coronelismo o fundamento são as relações de dependência pessoal, vigentes na instituição da moradia, no clientelismo o fator condicionante são as relações de dependência impessoal, gestadas no âmbito do assalariamento e suas garantias jurídicas. A maior independência adquirida na esfera das relações de trabalho traduz-se, em termos políticos, no chamado voto livre. Ao mesmo tempo, o enquadramento na lógica competitiva do mercado serve de modelo à conversão do voto livre em prática clientelista ${ }^{9}$. Em resumo, os fundamentos do clientelismo não devem ser buscados numa abstrata situação de carência das classes populares, mas na estrutura social particular que produz uma pobreza especifica.

\footnotetext{
${ }^{9}$ A idéia da lógica do comportamento eleitoral por imitação à lógica do mercado econômico encontra-se exposta em Schumpeter (1984), especialmente no capítulo XXII (Outra teoria da democracia). Uma restrição a ser feita ao enfoque schumpeteriano é que a lógica competitiva não se aplica ao conjunto das práticas político-eleitorais, mas apenas a um domínio particular.
} 
III. A ASCENSÃO DO CLIENTELISMO NO PIAUÍ

Procuramos ilustrar o enfoque sobre o clientelismo com o estudo das práticas político-eleitorais em uma subregião do Piauí, cujo processo de mudança política é representativo do que vem ocorrendo em grande parte do Nordeste rural brasileiro $^{10}$. Chegamos à conclusão básica de que, na área pesquisada, impôs-se, na década de 1990, a desagregação do coronelismo (voto de cabresto, confusão entre as esferas pública e privada) e a sua substituição pelo clientelismo (voto de barganha, distinção normativa entre o público e o privado).

\section{III.1 ASPECTOS DA MUDANÇA POLÍTICA}

Uma primeira manifestação da mudança política é o fato de a maioria dos eleitores ter passado do sistema do voto de cabresto para o sistema do voto livre: "O sistema da votação era que a gente tinha que votar pra o patrão. Ali era sujeito, num sabe? [Risos] Agora hoje em dia não é mais; o amigo é liberto, ele vota pra quem quer" (trabalhador rural, Barras (PI), em entrevista com o autor). Essa constatação é confirmada pelo fenômeno da dissociação do voto. Nas últimas eleições pôde-se observar que os eleitores tendem a desvincular o voto no candidato a Prefeito das opções partidárias desse candidato em outros níveis da eleição. Com efeito, os candidatos do PT aos cargos majoritários estaduais e federais têm recebido uma votação bem acima da candidatura a Prefeito. Inversamente, os partidos de direita têm tido uma votação mais elevada para o candidato municipal. A prática do eleitor de misturar as opções partidárias tornou-se possível em virtude do desencabrestamento do voto, uma vez que a fidelidade ao coronel implicava a vinculação das escolhas nos vários níveis da eleição.

No contexto em que o voto é livre, o eleitor tende a adotar expectativas diferenciadas, resultando na dissociação das opções partidárias, porque ele percebe que, conforme o nível do pleito, os interesses em jogo são distintos: quanto mais alto o nível da eleição, mais estratégicos eles são. De fato, o índice de votos em branco tende a ser maior

10 Para uma descrição mais abrangente das mudanças políticas no Nordeste brasileiro, consultar Bursztyn (1984), embora esse autor adote um enfoque do qual procuramos nos diferenciar. na eleição local do que na nacional e na estadual, o que denota uma relevância menor dada à eleição municipal. De qualquer modo, já não há, na região pesquisada, a vinculação necessária (como obrigava o coronel) entre a opção municipal e as opções estadual e nacional.

O voto livre se traduzia, na maioria dos casos, no voto de barganha, que assume uma forma mais sofisticada através do associativismo. A tendência é a de haver uma Associação em toda localidade rural ou em bairros do núcleo urbano, normalmente criada com o apoio da Prefeitura. A maioria dos líderes comunitários dão vida ao cabo eleitoral estatal, especializado não mais em prestar pequenos serviços individuais, mas, sim, em intermediar benefícios governamentais de consumo coletivo, sob a forma de programas assistenciais.

A proliferação de lideranças clientelistas no Nordeste rural recente exprime uma nova matriz ideológica do Estado. A ação estatal vem orientada pela metodologia de gestão participativa, formulada a partir de agências do capital internacional como o Banco Mundial, segundo a qual, as políticas distributivas devem romper junto aos beneficiados com a noção de assistidos e introduzir o conceito de clientes-consumidores, os quais passarão a ter uma influência na alocação e controle dos recursos, à medida que estiverem organizados, aumentando a eficiência (técnica e política) dos benefícios. A partir disso, as Prefeituras só poderiam firmar algum convênio de programas para o desenvolvimento rural, envolvendo os recursos internacionais ou nacionais, se a "população-alvo" estivesse engajada em associações locais. Isso induz a uma verdadeira explosão de Associações, criadas a partir do Estado. A estrutura organizacional das Associações - o legalismo, o burocratismo - contribui para a continuidade do vínculo das lideranças ao Estado. Encontram-se ligados aos programas a manipulação de estatutos, as cláusulas contratuais, a contabilidade, o gerenciamento - elementos que terminam transformando as lideranças das Associações mais em funcionários do Estado do que em representantes dos setores populares.

Esse fato revela os limites da participação comunitária, uma vez que ela pode ser, com relativa facilidade, apropriada pelos esquemas políticos dominantes, transformando-se em um mecanismo de conquistas eleitoreiras. O desafio para as lideranças comunitárias consiste em tomar os programas assistenciais como um meio para fortalecer a 
capacidade reivindicativa dos trabalhadores ${ }^{11}$.

O segundo indicador da mudança política refere-se ao perfil do quadro partidário. Na última década, as eleições municipais foram disputadas com mais competitividade, tendo crescido a votação dos pequenos partidos. Assim, o número de partidos concorrentes na eleição para Prefeito, que era de 5 em 1988, passou para 9 em 1992, e para 8 em 1996, ao mesmo tempo que o PMDB e o PFL, os dois maiores partidos, que somavam, em $1988,76,9 \%$ dos votos, totalizaram apenas $38,2 \%$, em 1992, e 42,4\%, em 1996. Anteriormente, os currais eleitorais impunham às eleições um caráter (quase) não-concorrencial.

Por sua vez, o espectro político ampliou-se, passando da situação dicotômica governo-oposição, típica do coronelismo, para o campo tripartido oposição de esquerda-governo-oposição de direita, mais sintonizada com o pressuposto da liberdade eleitoral. Em 1988, por exemplo, os partidos de esquerda (PT, PDT, PPS) detinham 6,6\% dos votos a Prefeito, aumentando para $8,5 \%$, em 1992, e para 9,2\%, em 1996.

A presença de grupos de esquerda nos aparelhos estatais em alguns municípios indica um certo pluralismo. É plausível supor que a participação de partidos de esquerda em governos locais tende a ser mais aceita pelas classes dominantes, à medida que a participação em tal nível implica menos riscos de desestabilizar o sistema hegemônico mais amplo. Isso ocorre porque, por um lado, as políticas que afetam a direção do crescimento econômico são geralmente decididas em âmbito nacional, atendendo aos requisitos do processo de acumulação capitalista, e, por outro lado, a maior competitividade no âmbito municipal contribui, de certa forma, para o processo de legitimação do Estado nacional, ao reforçar uma imagem de pluralismo (CASTRO, 1988), embora haja a possibilidade de a participação da esquerda em administrações municipais tornar-se um espelho para conquistas nos planos estadual e nacional (PRETECEILLE, 1986).

\footnotetext{
11 Há a possibilidade de a política social, quando inserida numa linha compensatória ou assistencialista, tornar pior a situação da classe trabalhadora, já que uma política classista poderia ter um resultado melhor do que a política clientelista: por exemplo, salários ao invés de programas assistenciais. Muitas vezes a distribuição de bens materiais se reduz a uma estratégia eleitoreira, sem trazer vantagens duradouras para o grupo ou setor beneficiado.
}

O terceiro aspecto da mudança, no sentido da ascensão do clientelismo, diz respeito à alteração do sistema da votação. Houve o deslocamento de mesas receptoras do núcleo urbano para as localidades da zona rural, evitando-se os deslocamentos da população no dia do pleito e oficializandose de algum modo o desmonte dos currais eleitorais. Esses eram, no dia da eleição, instalados na cidade, como forma de ostentar o prestígio do coronel e de realizar uma certa encenação do processo eleitoral. Já a votação próxima do local de moradia favorece os cabos eleitorais, que vêem diminuídos os custos de campanha (as despesas com o transporte e a alimentação dos eleitores só faziam sentido para o coronel, que tinha o voto do eleitor garantido) e podem controlar o cumprimento dos acordos com os eleitores.

A interpretação desse fato não é simples, já que se poderia ver no deslocamento das urnas para as áreas rurais um reforço ao poder dos coronéis, uma vez que eles poderiam ter o controle mais ostensivo do eleitorado de sua área. Mas o que se dá é justamente o contrário. Como vimos, o voto junto aos trabalhadores dependentes do proprietário pré-capitalista não apresenta o caráter da cidadania. Exprime, antes, uma mentalidade tipicamente medieval: trata-se da fidelidade ao chefe político (uma espécie de pequeno monarca). As eleições também não cumprem o papel de resolver as divergências entre os coronéis, já que é a violência, e não a democracia, que costuma decidir os desacordos. O voto tem sobretudo uma importância como instrumento de barganha dos grandes proprietários de terra frente aos grupos dominantes externos ao município.

Nesse sentido, cabe perguntar por que os coronéis não levavam as urnas diretamente às fazendas, preferindo o ajuntamento de eleitores no núcleo urbano no dia da eleição. De fato, no período da República Velha, os acontecimentos, por vezes, quase assumiam aquele aspecto caricatural, através da famosa eleição a "bico de pena", na qual o próprio mesário fazia as assinaturas da ata de votação, dispensando a presença dos eleitores. Como mostrou Telarolli (1982), essa e outras fraudes eram decorrência prática do caráter dependente do voto. Quando a facção rival resolvia não participar do pleito eleitoral, abdicando de disputar os votos flutuantes do eleitorado independente, ou um acordo distribuía os votos entre a facção governante e a opositora, a eleição a "bico de pena" era uma forma pragmática de evitar gastos com os eleitores, ao conduzi-los até o local de votação. 
No entanto, a ostentação das fraudes eleitorais chocava-se com a opinião pública dos principais centros urbanos. Principalmente a partir da Revolução de 1930, os coronéis tiveram que se enquadrar na aparência de legalidade das eleições. Para tornar o voto mais aceitável aos olhos dos residentes nos grandes centros urbanos, os coronéis e os caboclos realizam uma verdadeira encenação do processo eleitoral ${ }^{12}$. As eleições ganham um aspecto de festa, de ritual, comparável aos festejos religiosos. Fica, assim, compreensível por que os trabalhadores, quando falam da sua experiência de eleitor de cabresto, normalmente sorriem. Não é um riso de cinismo, tampouco de vergonha, mas de ironia ou galhofa. Como adverte Hobsbawm (1978, p. 55), a passividade dos camponeses tradicionais significa, antes de mais nada, uma "estratégia de sobrevivência". Em síntese, o financiamento de eleições pomposas no núcleo urbano, além de expressar o prestígio do coronel, poderia ser uma garantia da aceitação externa do produto - o voto.

Com a ruptura dos laços de dependência pessoal, a tradição dos currais eleitorais perde sentido, pois aquelas facilidades dadas aos eleitores no dia do pleito já não garantem o retorno do voto. É assim que os cabos eleitorais concorrentes preferem dividir igualmente entre si as despesas que a Justiça Eleitoral não tem condições de cobrir, como o transporte e a alimentação dos eleitores das áreas distantes onde não foi ainda instalada uma mesa receptora de votos. Portanto, o deslocamento das urnas de votação para os povoados (bairros rurais) é antes um indicador da fraqueza dos coronéis.

O quarto indicador da substituição do coronelismo pelo clientelismo se relaciona ao quadro das políticas sociais. Um fator de reforço à responsabilidade social das prefeituras - que, em razão do processo de urbanização acelerada, vêm sofrendo forte pressão em torno das demandas por equipamentos sociais - foi a mudança constitucional de 1988. A nova Carta propiciou uma injeção de recursos financeiros aos municípios: mais ricas,

\footnotetext{
12 A Justiça Eleitoral parece condenada ao papel de ator coadjuvante da comédia: realiza algumas punições exemplares a fim de satisfazer os escrúpulos da opinião pública dos centros urbanos, mas pouco faz para coibir de fato as fraudes (a troca de cédula, os mortos que votam, o alistamento de menores), que aumentam a eficiência dos currais eleitorais.
}

as prefeituras têm uma lista de obras a exibir e a barganhar votos. A Constituição imprimiu também um teor descentralizante às políticas sociais. As prefeituras devem não só aumentar a proporção em gastos sociais, mas também alterar a gestão das políticas, propiciando uma abertura de espaços à participação popular, que, devemos acrescentar, sob a aparência de controlar o Estado, pode converter-se em mecanismo de controle das próprias classes populares. Há indicação de que o gasto estatal social total elevou-se entre 1980-1992 (passando de 13,9\% para $17,1 \%$ em relação ao PIB nacional), expansão ocorrida num período em que se combinam a recessão econômica e a concentração da renda, o que acentua o papel compensatório e assistencialista das políticas sociais.

A dinamização das administrações locais tende a produzir efeitos mais rápidos nas subregiões do Piauí que apresentam uma estrutura econômica menos atrasada. Como mostrou um estudo avaliativo (NASCIMENTO, 1994), nas áreas atrasadas as despesas municipais apresentam um perfil menos eficiente e os mecanismos participativos (conselhos, comitês), quando implantados, tendem a não funcionar. O ritmo de expansão dos benefícios sociais, por exemplo, no Baixo Parnaíba, área de modernização econômica, apresenta-se maior do que a média estadual. Em relação ao setor educacional, enquanto entre 1983 e 1995 o número de matrículas nas escolas municipais em todo o estado aumentou de $38,8 \%$, na sub-região o acréscimo foi de $44,4 \%$. Houve também um decréscimo maior do que a média estadual nos alarmantes índices de analfabetismo: entre 1980 e 1991, o analfabetismo da população de 10 a 14 anos, na subregião diminuiu em $10 \%$, ao passo que no estado a queda foi de $8 \% 13$

Os efeitos das mudanças constitucionais, conjugados com os fatores internos (urbanização), foram percebidos como a fase da "política acelerada": "o Prefeito hoje que entrar na prefeitura e não fizer nada, ele está condenado a ser banido do quadro político. [...] Essa é a política acelerada. [...] O Prefeito tem que fazer o que todo mundo veja" (ex-vereador do PT, em entrevista com o

\footnotetext{
13 A taxa média de analfabetismo da população de 10 a 14 anos na sub-região piauiense, em 1991, é de 56\%. As taxas no Nordeste e no Brasil são, em 1990, respectivamente de $33,0 \%$ e $14,4 \%$.
} 
autor). O que explica a maior eficácia administrativa na sub-região, comparada ao desempenho médio do estado, é provavelmente menos uma pressão da máquina municipal por parte dos setores populares, mobilizados quanto ao uso dos recursos, do que a busca da burocracia em multiplicar os apoios políticos, ou seja, uma política clientelista.

O quinto dado significativo da mudança política é a acentuação da modernização das administrações municipais - impulsionada pela urbanização e pelo enquadramento nas diretrizes dos programas governamentais federais. Passou-se a dar importância aos critérios de eficiência técnica, necessários a uma gestão que enfrenta um quadro mais complexo de demandas.

Embora as questões de eficiência técnica sejam relevantes, o aspecto fundamental parece estar na questão da eficiência política, ou seja, quais os reais objetivos que as políticas sociais cumprem. Mesmo as ações que procuram beneficiar os setores populares mais carentes não deixam de levar em conta os interesses dominantes. Além do mais, o funcionamento concreto do Estado capitalista (sempre pressionado em grau superior pelos membros da classe dominante) inviabiliza o pleno sucesso de qualquer política social no sentido de atender às necessidades das classes populares, pois, em última análise, existem sempre os obstáculos à tributação dos lucros.

De qualquer modo, a contraface da modernização administrativa foi o fim do controle monopólico do aparelho municipal do Estado pela propriedade agrária, estabelecendo-se, a partir de então, a distinção (normativa) entre as esferas pública e privada. De fato, a estrada, a escola, o chafariz, o posto médico deixaram de ser atividades custeadas ou intermediadas pelo fazendeiro e passaram à responsabilidade das administrações municipais, que se reaparelharam no sentido de gerir os recursos e os equipamentos de uso coletivo como públicos.

Em relação ao emprego estatal, por exemplo, com a vigência dos princípios de organização burocrática do Estado (que implica a norma do recrutamento do pessoal não mais com base em favores pessoais, mas de acordo com o sistema do mérito), a utilização do emprego como recurso de barganha política tende a restringir-se aos escalões superiores. É que, dadas a hierarquia e a rígida disciplina do aparelho burguês do Estado, no qual os escalões inferiores devem se submeter estritamente às or- dens dos superiores, torna-se estratégico garantir o controle do topo do aparelho estatal.

No domínio coronelístico, a substituição de partido (ou facção) no governo normalmente atingia o emprego no nível não-superior (professores, enfermeiros, vigias): “Antes de 1988, no Piauí era assim. As pessoas não tinham seus empregos garantidos nos municípios. Com a Constituição de 88, veio a estabilidade no emprego. [...] Foi uma revolução para nós, em termos da estabilidade das pessoas. Porque hoje o Prefeito que é eleito não pode jogar fora o inimigo político, quem não votou nele. Mas antes podia" (ex-assessor da SEPLANPI, em entrevista com o autor).

Convém fazer a ressalva de que, naquelas subregiões onde não se implantaram as condições de predomínio do clientelismo, muito provavelmente os dispositivos constitucionais continuam sendo letra morta, no que diz respeito ao emprego estatal no nível não-superior.

As subregiões de "modernização econômica" piauienses acompanham a tendência nacional de expansão de gastos com o pessoal da administração estatal. No Baixo Parnaíba, por exemplo, os dispêndios de pessoal, relativos ao orçamento municipal, entre 1989 e 1995, cresceram de $21,0 \%$ para $25,2 \%{ }^{14}$. Tal crescimento - em flagrante contradição com as propostas de redução do Estado e revisão de suas atribuições - deixa de ser surpreendente se levarmos em conta que o empreguismo atinge sobretudo os escalões superiores dos aparelhos estatais, atendendo, em boa parte, ao imperativo de busca de sustentação política.

Outro fator que influenciou a expansão do emprego estatal foi a transferência para os níveis estadual e municipal de programas sociais federais. Nesse caso, porém, mesmo que o acréscimo de pessoal tenha sido necessário - com a criação de determinadas secretarias e o reaparelhamento de outras, a fim de atender a novas atribuições -, não está excluída a possibilidade de manipulação dos cargos para fins clientelísticos, especialmente nos escalões superiores. É possível ainda que as indicações para os postos dirigentes tenham sido feitas sem desconsiderar a competência da pessoa

14 O total de dispêndios com o pessoal empregado por estados e municípios no Brasil, entre 1988 e 1990, cresceu de 4,7\% para 6,8\% do PIB nacional (REZENDE, 1995). 
escolhida, mas evidentemente dentro de um leque de opções determinadas pelas afinidades políticas e sociais.

Houve também a criação de novos municípios, incentivada pelas novas regras constitucionais com respeito à partilha de tributos e transferências federais. Porém, como os municípios na região piauiense são de médio e pequeno portes, é pouco provável que o desmembramento de novas unidades político-administrativas tenha obedecido a critérios urbanísticos e demográficos mais do que aos de acomodação das clientelas políticas.

Um último elemento expressivo da mudança no sistema político regional vincula-se ao crescimento dos partidos de esquerda. Somente num quadro de ascensão da política clientelista - especialmente na sua variante estatal, o que pressupõe a modernização burguesa da máquina governamental e, conseqüentemente, a identificação do público com o conjunto da coletividade - tornase plausível a crítica ao favoritismo político, abrindo espaço para a proposta dos partidos de esquerda de gestão honesta (isto é, universalizante) da coisa pública. No domínio coronelístico, a crítica ao favoritismo era sem eficácia, pois ali vigorava o sentimento de que os recursos estatais eram propriedades da facção governante.

Enfim, o conjunto de indicadores da mudança política sintetiza-se no fato de que as principais prefeituras da região passaram ao domínio de cabos eleitorais eleitos em oposição aos coronéis e identificados com a política comunitária.

\section{III.2 AS RAZÕES DA ASCENSÃO DO CLIENTELISMO}

O fim do domínio do coronelismo correspondeu, fundamentalmente, às transformações da estrutura agrária regional, as quais dizem respeito à substituição da grande propriedade pré-capitalista (absorvedora de um enorme contingente de trabalhadores dependentes), pelas formas de propriedade capitalistas (assentadas em relações de trabalho mercantis). De um lado, ocorre a modernização do latifúndio através do crescimento de uma pecuária capitalizada, tendo como principal incentivo as linhas de crédito governamentais, o que implicou a expulsão dos trabalhadores-moradores das grandes propriedades e a adoção crescente do trabalho assalariado (principalmente temporário). De outro lado, os projetos governamentais de apoio à "pequena produção" - especialmente aqueles que, em razão da forte pressão demográfica e dos conflitos de terra, adotaram uma política de redistribuição de terras - contribuíram para a renovação da pequena propriedade independente, voltada para a produção mercantil de alimentos. Um indício de que a agropecuária na subregião piauiense já não está predominantemente ligada ao latifúndio senhorial é o fato de que, após algumas décadas de estagnação, a atividade agropecuária voltou a crescer e registra ganhos de produtividade tanto na grande propriedade quanto na pequena.

A modernização pecuária, que envolve, entre outros aspectos, a alternância dos roçados com o ciclo da pastagem, provoca uma perda crescente da população rural (expulsão dos moradores). No período $1970-80$, houve uma queda de $8,4 \%$ da população rural no Baixo Parnaíba piauiense, enquanto entre 1980-91 a taxa de evasão aumentou para 9,2\%. Esse fluxo migratório tem características distintas da emigração das décadas de 1960 e 1970, relacionada à crise da produção extensiva do latifúndio e à atração dos grandes centros urbanos e industriais. Na fase recente, os trabalhadores expulsos das propriedades rurais, ao invés das grandes cidades, detêm-se nas periferias dos pequenos núcleos urbanos, de onde passam a buscar trabalho nos latifúndios transformados.

Em parte em razão das mudanças na estrutura latifundiária, implicando novas relações de classes, o perfil dos núcleos urbanos modifica-se. Eles vêem surgir, em curtíssimo período de tempo, bairros inteiros, compostos por um proletariado agrícola em formação (trabalhadores diaristas, pequenos rendeiros). É assim que, entre $1970 \mathrm{e}$ 1991, a população urbana mais que duplicou no Baixo Parnaíba, aumentando em 142,8\%. Em termos proporcionais, a população urbana, que, em 1970 , representava $21,6 \%$ do total populacional, passou, em 1991, para 39,2\%.

Em geral, o urbano pré-capitalista caracterizase pela proximidade física dos grupos sociais, embora a mistura seja marcada pela distância social a partir dos gestos, roupas, cor da pele (uma herança do escravismo), com os habitantes agregando suas casas, nesse tipo de cidade, sem algum planejamento. Já o urbano capitalista define-se pela segregação social: de um lado, bairros proletários, carentes de equipamentos sociais e, de outro, bairros burgueses, bem servidos de tais equipamentos. O solo urbano, por sua vez, entra na lógica do mercado, tornando-se valorável segundo a sua 
extensão e proximidade do centro comercial, com a terra esquadrinhada em lotes que se adquirem de acordo com o poder aquisitivo (ROLNIK, 1994).

A zona rural também começa a apresentar uma nova configuração. Os assentamentos substituem o isolamento físico, vigente no interior do latifúndio, pela junção dos assentados no povoado. Aqui, o pequeno produtor dispõe de um lote de residência, separado das terras de roçados. Isso viabiliza o uso de equipamentos públicos, como água, luz, escola. Por sua vez, o espaço do mercado impõese: assim como a produção deve circular para chegar ao consumidor, as pessoas também circulam, seja para adquirir bens que não produzem, seja para ir ao banco, receber aposentadoria etc. Nesse contexto, as estradas são piçarradas e os caminhões fazem "horários" diários, os jovens podem continuar os estudos na cidade sem ter que abandonar a família no campo, e, com a luz elétrica, chegam a geladeira e a televisão. Enfim, reforçase o sentimento de pertença à "sociedade local" (antes identificada quase tão-só com os residentes no núcleio urbano, basicamente com as famílias dos grandes proprietários de terra e de seus prepostos). Tanto é assim que se tornou pejorativo referir-se aos pequenos proprietários agrícolas como pessoas "do interior" 15 .

Em síntese, a burocracia estatal, através dos instrumentos de política econômica e dos projetos especiais governamentais, converteu-se em um dos principais agentes desencadeadores do desenvolvimento capitalista na área periférica. No entanto, a ação estatal significou a manutenção de um modelo espoliador do desenvolvimento capitalista, relegando as regiões periféricas a uma integração seletiva - uma forma de atenuar os conflitos nas áreas de alta tensão social, deixando margem para a ação predatória do capital estrangeiro nas áreas agrícolas mais rentáveis.

Poder-se-ia objetar que a constatação de um paralelismo entre a mudança na esfera políticoeleitoral - do voto de cabresto para o voto livre -

\footnotetext{
15 Cabe observar que o tipo de pequeno proprietário encontrado na região não se compara com o da agricultura familiar mais desenvolvida, como em certas áreas do Sudeste do país, pois o pequeno proprietário de agricultura menos desenvolvida muitas vezes tem de complementar a sua renda com a sujeição ao trabalho assalariado em outras propriedades.
}

e a transformação na esfera econômica - da sujeição na propriedade rural para a liberdade do mercado de trabalho - não permite a inferência de uma relação causal entre elas. No entanto, não vemos outro fator plausível que desempenhasse o papel de explicar a mudança da prática políticoeleitoral.

Seria esse fator uma alteração de mentalidade dos grandes proprietários de terra, que, em razão de condições históricas herdadas (economia latifundiária auto-suficiente, baixa qualificação da força de trabalho), estavam apegados a uma passividade crônica e ao desestímulo ao comportamento empresarial? Mas a herança colonial agrária, num contexto em que outras regiões tomaram a dianteira do desenvolvimento capitalista, criandose um diferencial de produtividade desfavorável aos investimentos na região atrasada, tornava racional (do ponto de vista dominante) a permanência do latifúndio pré-capitalista - o que significa que a mudança de mentalidade dependia de outros fatores desencadeadores da metamorfose do latifúndio na empresa rural. Pode-se, afinal, indagar por que o coronel mudaria de mentalidade se ele não tinha o sentimento da irracionalidade do latifúndio.

Ou o fator principal do fim do coronelismo seria a recomposição do grupo político dirigente no nível estadual? Ora, nada impedia, como sugere Martins (1991), que os coronéis utilizassem o acesso à máquina governamental para converter os seus velhos latifúndios em empresas capitalistas - o que torna duvidosa a afirmativa de que as suas presenças nas cúpulas do aparelho estatal inviabilizassem a superação do latifúndio obsoleto.Convém notar que uma mudança na composição do grupo dirigente subregional, em detrimento da presença direta dos fazendeiros, não implicaria, por si só, uma desagregação do coronelismo. Como mostrou Faoro (1995), o médico, o advogado e outros podem estar a serviço do coronel. Para que a recomposição do grupo dirigente subregional se faça contra os coronéis e seus prepostos, deve ser antecedida pela desagregação dos currais eleitorais, ou seja, da propriedade agrária senhorial. Afinal, é o controle de um elevado contingente de força de trabalho que confere ao grande proprietário da terra, embora sem expressão econômica externa ao município, um alto prestígio social e a eficácia político-eleitoral.

Dessa forma, as objeções a um outro fator ex- 
plicativo levam-nos a sustentar, com alguma margem de segurança, a relação causal entre a transformação agrária e a mudança político-eleitoral. Cabe ainda apontarmos uma hipótese explicativa para a relativa defasagem entre a mudança econômica (a partir da década de 1970) e a política (década de 1990). Tal explicação pode ser encontrada no elemento sociológico referente aos conflitos de gerações. Os valores da fidelidade política, apesar de sua base econômica ter sido corroída, perduraram, nalguma medida, na mentalidade dos mais velhos, que têm, em regra, mais dificuldades de adaptar-se aos valores do novo contexto. Como observou Pierre Bourdieu, "a velhice também é um declínio social, uma perda de poder social e através deste viés, os velhos têm, no que se refere aos jovens, uma relação que também é característica das classes em declínio; [os velhos] são contra tudo aquilo que muda, tudo aquilo que se move, justamente porque eles deixaram o futuro para trás, enquanto os jovens se definem como tendo futuro, como definindo o futuro" (BOURDIEU, 1983, p. 118-119).

Embora nem todos os velhos fossem conservadores, foi necessário o intervalo de uma geração para que outros valores políticos (como a ideologia clientelista) se impusessem: "Depois que eu morei aqui [na cidade], ainda tinha ainda [o voto cativo]. Mas depois mudou. Nós ficamos libertos" (trabalhador rural, em entrevista com o autor).

Procuramos caracterizar a política comunitária, emergente nas áreas de modernização agrária capitalista, através do conceito de clientelismo estatal. Define-se como a modalidade de clientelismo na qual os "políticos de profissão" distribuem recursos "públicos" e favores ligados às instituições governamentais, em troca de sustento eleitoral (CACIAGLI, 1982, p. 326). Os cabos eleitorais tendem a dirigir-se a comunidades inteiras, e menos a pessoas privadas. "O clientelismo passa a ter um caráter grupal e impessoal, visto que é mediado pela alocação de benefícios [aparentemente] públicos, o que implica um mínimo de racionalidade administrativa" (KERBAUY, 1992, p. 166).

O surgimento da variante estatal do clientelismo representa, em boa medida, uma forma de os partidos de direita competirem com a esquerda, pois o clientelismo privado (envolvendo recursos dos candidatos e destinados a indivíduos particulares) mostra-se insuficiente como estratégia eleitoral diante da crescente mobilização popular em torno de demandas surgidas com o desenvolvimento econômico e urbano. A classe dominante passa a apoiar uma política de "grupos", rompendo aparentemente com o apelo isolado aos indivíduos, com o objetivo de competir no terreno das organizações populares. Assim, um partido conservador pode praticar um "clientelismo de massa", ou seja, a distribuição de recursos de consumo coletivo, envolvendo as "associações comunitárias". A favor do clientelismo estatal conta o fato de que a mobilização e a participação populares, no nível local, podem ser reapropriadas com alguma facilidade pelos políticos profissionais (JOBERT, 1983).

Com o desenvolvimento capitalista possibilitando alguma estabilidade de emprego e uma melhor distribuição de renda e com o aumento da organização das classes populares, a tendência é o declínio do clientelismo privado, forma mais explícita de manipulação, em benefício do clientelismo estatal, modo mais sofisticado de controle. Isso ocorre "não porque os laços individuais não são mais necessários - eles ainda são necessários -, mas por causa de seu retorno decrescente para políticos e outros grupos politicamente dominantes" (THEOBALD, 1983).

Uma das razões apresentadas para explicar a difusão do clientelismo (privado ou estatal), junto aos trabalhadores rurais seria a piora das suas condições econômicas. Argumenta-se, a exemplo de Rego (1993), que a saída do trabalhador do interior da grande propriedade fundiária e a sua ida para a periferia do núcleo urbano poderia implicar um rebaixamento nas suas condições de vida. Não dispúnhamos de uma técnica de pesquisa que pudesse aferir o bem-estar material do trabalhador nas duas situações. No entanto, podemos notar que se, por um lado, o trabalhador da periferia que recebe um salário visse restringida a sua opção de consumo "direto" (bens obtidos do uso da terra), ele, por outro lado, ampliaria o consumo "indireto", através do acesso aos equipamentos urbanos. De qualquer forma, o argumento pressupõe um nexo causal entre a deterioração nas condições econômicas capitalistas e o clientelismo eleitoral. Mas isso também não é evidente.

Há elementos para se reconhecer o contrário, ou seja, o fato de que a deterioração das condições econômicas capitalistas não necessariamente leva ao clientelismo ou, mais genericamente, a um comportamento político conservador. É possível, numa conjuntura de crise econômica (desemprego, 
inflação, diminuição da renda), as classes populares voltarem-se para uma política progressista. Como destacam vários estudos, nos Estados Unidos a classe dos trabalhadores manuais, durante a conjuntura recessiva da década de 1970, apresentou um comportamento político não-conservador: valorizou as questões nacionais, votou na oposição e aumentou sua participação política (KERNELL, 1977; WEARTHFORD, 1978; FIORINA, 1978). Mais especificamente, os trabalhadores manuais conectaram às suas experiências pessoais uma avaliação das políticas governamentais nacionais, ligando, por essa via, o voto para Presidente da República às questões econômicas e sociais. Nesse contexto, o voto adquiriu um caráter mais retrospectivo do que prospectivo, assumindo a feição do voto negativo, isto é, de punição ao partido governante (FIORINA, 1978). Ao mesmo tempo, foi dada à questão política nacional um conteúdo específico: a defesa do bemestar social antes da questão do crescimento econômico (IRELAND, 1973, p. 179-180).

A ideologia capitalista, ao opor o interesse individual privado ao interesse geral público, tende a desconectar a experiência pessoal de uma avaliação das políticas nacionais ${ }^{16}$. Exige-se dos trabalhadores, no plano nacional, um comportamento altruista, em nome do interesse público. A valorização do interesse pessoal é admitida na política local, ligada a problemas mais restritos. A crise dos anos 70, conseqüentemente, criou as condições para a rejeição desse mecanismo ideológico, à medida que o voto da classe trabalhadora manual no Partido Democrata esteve ligado à identificação do partido com a defesa de uma política nacional de bem-estar social, a qual se refletiria, ampla e diretamente, nas suas experiências de vida. Enfim, o fator econômico, numa conjuntura específica, atuou como um elemento determinante do comportamento político dos trabalhadores, mas o efeito foi na direção oposta à esperada pela tese de que a pobreza é causa do clientelismo ou, mais em geral, do conservadorismo político.

Inversamente, as condições de ascensão eco-

\footnotetext{
16 Como mostrou Burbank (1997), os "contatos pessoais" (vizinhança, amizade etc.), em cidades americanas e inglesas, pouco influíram na opção partidária - uma referência, antes de mais nada, nacional -, constatação válida tanto para a classe trabalhadora manual quanto para a classe média.
}

nômica das classes populares não necessariamente induzem ao conservadorismo político. É o caso do aparente paradoxo discutido por Labrousse (1970): a massa de camponeses independentes na França aderiu à revolução numa situação, ao longo do século XVIII, de melhoria econômica. Como esclarece o historiador francês, devido à estabilização dos preços de cereais, fonte de graves crises de fome de períodos anteriores ao século XVIII, a França assistiu, naquele século, a uma estabilidade econômica inusitada. No entanto, a crise conjuntural do final do século, menos grave do que as anteriores, não foi sentida dessa maneira - suscitando uma oposição sem precedentes das classes populares à ordem social. Tal mudança de comportamento é atribuída à formação de um novo "estado de espírito" junto às classes populares, difundido pela burguesia (industrial, comercial e financeira), já portadora de uma "consciência coletiva em progresso": "Para além da maturidade econômica da burguesia, se afirma lentamente a maturidade de sua consciência social. De classe em si, ela torna-se classe para si. Exerce, ao longo do século XVIII, sua atração de classe em ascensão sobre as frações de outras classes ou ordens. [Por sua vez] as massas camponesas, com seus quadros enriquecidos e independentes, multiplicados durante a expansão econômica generalizada, suscitam elas mesmas suas necessidades diante do inimigo comum" (LABROUSSE, 1970, p. 740).

A burguesia, como enfatiza E. Labrousse, estava em condições de absorver e difundir as novas idéias filosóficas, morais e políticas, em contraposição à visão de mundo tradicional da Igreja e dos senhores feudais. Os camponeses, por sua vez, encontraram no novo espírito que se difundia um estimulante para a sua ira contra os direitos feudais.

Em suma, nem o declínio nem a ascensão econômica das classes populares, nos quadros do capitalismo, implicam necessariamente um comportamento político conservador, em particular o clientelismo.

Um outro tipo de argumento evocado para explicar a vulnerabilidade do eleitorado ao apelo clientelístico seria a falta de "consciência política". Se por essa expressão pretende-se indicar o sentimento dos valores básicos da cidadania, então não é correto afirmar que falte aos trabalhadores essa consciência. Como atestam os depoimentos abaixo, os trabalhadores têm consciência do elemento 
universalizante da cidadania.

"O que deve fazer [um Prefeito]? É trabalhar a bem do município, não olhar pra quem vai beneficiar; porque eu sou um eleitor, dizer que vai beneficiar aquele" (pequeno proprietário, Esperantina (PI), em entrevista com o autor).

"Eu tenho desgosto é da escravidão que eles [políticos] querem fazer com o povo. Um Prefeito tem o direito de administrar a prefeitura toda, não só quem é com ele [...]; o direito dele é do tanto que ele me ajudar, ajudar aquele ali que não ajudou ele" (membro da Associação do Povoado Fazenda Nova, Esperantina (PI), em entrevista com o autor).

"E um governo também que abeneficiasse a população, não só a população, como todos em geral. Hoje, a gente vê a maioria dos bens e as facilidades para o rico, pra os interesses dele" (moradora, Tapuio, Esperantina (PI), em entrevista com o autor).

Na verdade, a ideologia clientelista só pode se impor onde existe um dos elementos básicos da cidadania: o sentimento da liberdade individual, ao qual se ligam, de forma imediata, dois outros elementos-chaves: o sentimento de pertença à comunidade nacional e a percepção do Estado como representante do interesse geral dessa comunidade. Tais elementos provocam aquilo que Marilena Chauí, analisando a "cultura popular" no Brasil, designou de "consciência trágica", isto é, aquela que descobre a diferença entre $o$ que é e $o$ que deveria ser, e que por isso resiste à ordem estabelecida, mas não chega a constituir uma outra existência social, porquanto aprisionada nas determinações da realidade atual e orientada por uma perspectiva irrealista (CHAUÍ, 1986, p. 178). Acrescentamos a ressalva de que, em momentos críticos, os trabalhadores podem extrapolar os limites da ideologia da cidadania: "Mas de qualquer maneira, não tem quem [governo] sirva a todos" (membro da Associação do Povoado Fazenda Nova, Esperantina (PI), em entrevista com o autor).

Há que se levar em conta também que os trabalhadores têm um conhecimento dos mecanismos da manipulação do voto. A avaliação de que os políticos são na maioria "desonestos", "interesseiros", defensores "da panela deles" indica uma percepção das formas pelas quais são eleitos. As classes dominadas não apenas têm um conhecimento da manipulação eleitoral, mas também ten- dem a jogar com essa situação como uma "estratégia de diminuição de riscos" (JOBERT, 1983). Trata-se menos de um conformismo, resultado da ignorância, que de uma prática defensiva, pois não se vislumbram vantagens concretas em romper com os esquemas de manipulação.

Agora, se por "consciência política" devemos entender uma "consciência de classe", então de fato a fragilidade das organizações populares abre espaço para o domínio clientelista. No plano sindical, a estrutura oficial estendida aos trabalhadores rurais e o convênio com o FUNRURAL induziram várias lideranças a se tornarem os agentes precursores do clientelismo estatal no campo, à medida que elas se acomodaram ao papel assistencialista atribuído ao sindicato pelo Estado. No plano partidário, a valorização da democracia capitalista não como um meio para fortalecer os grupos reivindicativos populares, mas como um fim em si mesmo, enfraqueceu a posição do principal partido de esquerda (o PT) frente aos aparelhos do Estado. Por fim, a implantação acelerada do capitalismo no campo, repetindo o padrão da industrialização nacional, opõe fortes obstáculos à cristalização das solidariedades no interior da classe trabalhadora e, consequentemente, à sustentação de um comportamento político de classe independente.

\section{III.3 CONSIDERAÇÕES SOBRE A MUDANÇA POLÍTICA}

A burocracia estatal e a burguesia industrial foram os agentes e os principais beneficiados (incluindo-se o capital estrangeiro) da substituição do coronelismo pelo clientelismo (estatal). Os burocratas converteram-se, com base na distribuição de recursos governamentais e equipamentos sociais, em novo grupo governante no nível local, ao passo que a burguesia industrial obtém, com a modernização agrária, um novo mercado de bens intermediários (máquinas e implementos agropecuários). Por sua vez, o capital financeiro internacional pode ver atenuado o seu desgaste ideológico, decorrente do freqüente impacto, no noticiário mundial, das tensões e conflitos sociais nas áreas "atrasadas".

Em termos da contraposição partidária, no Piauí, o bloco capitalista (novos agropecuaristas, burocratas) agrupou-se no MDB, depois PMDB, enquanto o bloco pré-capitalista (latifundiários, classe média tradicional) alojou-se na ARENA, depois PDS e PFL. Tal confronto de forças sociais 
e partidárias repercutirá nas eleições ao governo estadual em 1994 e 1998. Em ambos os pleitos sai vitorioso o candidato do PMDB na disputa com o candidato do PFL. Nesse sentido, ganha plausibilidade a afirmativa de que os resultados das eleições de Governador significaram o desalojamento da oligarquia senhorial como força detentora do aparelho regional do Estado $^{17}$.

A revolução burguesa no Piauí, como de resto no Nordeste e no Brasil, pode ser caracterizada através do padrão geral denominado de a "via prussiana" da transição. Lênin usou pela primeira vez esse termo para indicar a diferença de resolução da questão agrária nos Estados Unidos, onde foi feita uma reforma agrária, e na Alemanha, onde não houve essa reforma. Em Lukács, a noção de via prussiana da transição capitalista adquiriu um significado não apenas econômico, mas também político, no sentido de que é a variante que representa a exclusão da democracia (REGO, 1996).

O problema da conceituação lukacsiana consiste em inferir do processo econômico (ausência da reforma agrária) um padrão de regime político (não-democrático), pois nem sempre a transição capitalista sem a reforma agrária implicou a ausência do regime democrático. É verdade que essas experiências de democracia tendem a ser mais limitadas (Alemanha, Itália), comparadas com os casos nos quais foram feitas reformas agrárias (EUA, França) ${ }^{18}$. Mas há exemplo em que a distribuição da terra foi feita sem que se produzisse uma democracia mais ampla (México). No Brasil, como no Nordeste e no Piauí, onde a modernização da grande propriedade agropecuária (e não a reforma agrária) foi o carro-chefe da mudança no campo, formou-se uma democracia capitalista, embora,

17 O conceito de força detentora refere-se à ocupação dos cargos dirigentes do aparelho de Estado. Nem sempre o recrutamento dos quadros dirigentes estatais tem a sua origem na força social hegemônica. Por vezes, essa força dominante delega a membros de um outro grupo social a concretização de sua hegemonia política. Há, portanto, a possibilidade de dissociação entre a força hegemônica no interior do bloco de classes dominantes e a força detentora do aparelho de Estado. Foi esse o caso apontado por Marx em O 18 Brumário, em que a Monarquia francesa (de origem agrária), entre $1830 \mathrm{e}$ 1848 , realizava a hegemonia política da burguesia "financeira" (POULANTZAS, 1986).

18 Sem contar que a democracia foi instável na França, como, por exemplo, a instauração de duas ditaduras bonapartistas. por motivos que procuramos apontar, sob a limitação de práticas clientelistas.

Chegamos, portanto, a um diagnóstico diferente do encontrado em boa parte dos estudos sobre o Nordeste rural brasileiro, os quais negam a existência da transição política capitalista, embora reconheçam as mudanças na estrutura econômica. Os autores dessa corrente de trabalhos, ao definir a transição política capitalista de um modo restrito e exigente, fazendo-a equivalente à política de classe independente ("emancipação política das classes populares"), deixam de reconhecer como "democrático-modernas" as experiências em que a política não atinge um patamar tão elevado - sendo induzidos a afirmar a persistência de práticas précapitalistas ("neocoronelismo"). No entanto, as classes populares podem, sim, incorporar-se ao regime democrático capitalista, como no caso que estudamos, através de um mecanismo participativo mais limitado - o clientelismo - do que o encontrado nalgumas democracias capitalistas clássicas (a política de classe independente) ${ }^{19}$.

É interessante indagarmos ainda por que a maioria dos analistas resiste em diagnosticar uma revolução política (burguesa) no Nordeste agrário brasileiro. Do ponto de vista teórico, a noção de "novos coronéis" bloqueia a percepção do clientelismo como uma prática política burguesa, à medida que aquela noção denota que algo mudou, mas uma dimensão essencial do passado pré-capitalista permanece. Há uma razão de ordem epistemológica para esse procedimento: a defesa de que, nas ciências sociais, os conceitos têm um sentido flexível, ou seja, podem alterar as suas premissas, em correspondência ao movimento da história. Assim, se num dado contexto o termo coronelismo incide sobre o voto de cabresto, noutro, ele poderia referir-se ao voto de barganha. Mas, dessa forma, entre o "velho" e o "novo" coronelismo, o que

\footnotetext{
19 Em contraposição ao modelo francês de revolução burguesa, Gramsci (1968) forjou o conceito de "revolução passiva”, uma modalidade de transição política mais difundida nas formações sociais capitalistas. Trata-se de um processo de mudança que ocorre "pelo alto", isto é, sem uma mobilização das classes populares para o empreendimento de transformações mais amplas. O padrão prevalecente é o de cooptar as lideranças das classes populares, impedindo-se que as pressões dos "de baixo" amplie as conseqüências da ruptura com a antiga ordem, como uma reforma agrária de caráter maciço.
} 
resta é uma relação de analogia, pela qual certos aspectos abstratos (dominação, particularismo) são percebidos em comum, deixando-se de lado a especificidade. Do ponto de vista político, o uso da noção de "neocoronelismo" pode revelar um apego dos analistas às tradições latifundiárias, visto que ela minimiza a importância da mudança da estrutura agrária como fator suficiente para o fim do coronelismo.

\section{CONCLUSÃO}

A barganha político-eleitoral, em particular a distribuição particularista de bens aparentemente públicos (o clientelismo estatal), não deve ser vista como incompatível à democracia capitalista. Essa, que não se restringe ao padrão ideológico do universalismo de procedimento, engloba também a alternativa clientelista. $\mathrm{O}$ clientelismo, longe de ser um "desvio" (disfunção), é um fato "normal" (funcional) ao interior de tal democracia.

O fundamento das práticas clientelistas não se encontra numa herança pré-capitalista, mas, sim, na própria formação social capitalista. A cidadania política comporta um modelo competitivo análogo ao mercado econômico. Na verdade, a presença de relações de produção pré-capitalistas no interior de uma democracia capitalista suscita um outro tipo de prática política, qual seja, o coronelismo.

$\mathrm{O}$ crescimento da pobreza (desemprego, inflação, diminuição da renda) no seio da classe trabalhadora não explica a prevalência do clientelismo em certos contextos democráticocapitalistas. É possível, numa conjuntura de crise econômica, as classes populares voltarem-se para uma política não-clientelista, como nos Estados
Unidos da década de 1970, quando os trabalhadores manuais valorizaram as questões nacionais, votaram na oposição e aumentaram a sua participação política.

Nem tampouco a "falta de consciência" dos valores básicos da cidadania política pode ser evocada como a causa da força do clientelismo. É possível encontrar, em contextos em que tal comportamento político predomina, como o estudado por nós no Nordeste brasileiro, uma clara consciência de elementos da cidadania política: liberdade, universalidade. Devemos levar em conta ainda que os trabalhadores têm um conhecimento dos mecanismos de manipulação do voto. A avaliação de que os políticos são na maioria "desonestos", "interesseiros", defensores dos "da panela deles", indica a percepção das formas pelas quais são eleitos. As classes dominadas, enquanto não vislumbram vantagens concretas em romper com os esquemas de manipulação, tendem a jogar com os mesmos como uma "estratégia de diminuição de riscos".

A fragilidade das organizações populares (sindical e partidária) e a implantação acelerada do capitalismo no campo, criando obstáculos à cristalização da solidariedade de classe, são fatores que jogam um papel estratégico na explicação da prevalência clientelista no Nordeste brasileiro. As organizações populares enfrentam o desafio de converter os benefícios materiais e os espaços democráticos em meios de fortalecer a capacidade reivindicatória e a independência política das classes populares.

Recebido para publicação em 16 de janeiro de 2000

Francisco Pereira de Farias (f.farias@uol.com.br) é doutorando em Ciências Sociais na Universidade Estadual de Campinas (UNICAMP) e Professor do Departamento de Ciências Sociais da Universidade Federal do Piauí (UFPI).

\section{REFERÊNCIAS BIBLIOGRÁFICAS}

ANDRADE, M. C. 1980. A terra e o homem no Nordeste. São Paulo : Ciências Humanas.

BOURDIEU, P. 1983. A juventude é apenas uma palavra. In : Questões de sociologia. Rio de Janeiro : Marco Zero.

BURBANK, M. 1997. Explaining Contextual Effects on Vote Choice. Political Behavior, v.
19, n. 2, p. $113-132$.

CACIAGLI, M. 1982. Il clientelismo nel Terzo Mondo. Rivista Italiana di Scienza Politica, v. XIX, n. 2, p. 321-331.

CASTRO, M. H. 1988. Equipamentos sociais e política local no pós-64 : dois estudos de caso. Espaços e debates, São Paulo, a. VIII, n. 24, 
p. 64-74.

CERI, P. 1984. Sei tipi di scambo sociale. Rassegna Italiana di Sociologia, Bologna, v. 25, n. 1, p. 7-43.

CHAUÍ, M. 1986. Conformismo e resistência. São Paulo : Brasiliense.

DANIEL, C. 1988. Poder local no Brasil urbano. Espaço e debates, São Paulo, a. VIII, v. 24, p. 26-39.

FAORO, R. 1995. Os donos do poder. Vol. II. $10^{\mathrm{a}}$ ed. Porto Alegre : Globo.

FARIAS，F. P. 1999. Do coronelismo ao clientelismo : a transição política capitalista no Noroeste do Piauí (1982-1996). Campinas. Dissertação (Mestrado em Ciência Política). Universidade Estadual de Campinas.

FIORINA, M. P. 1978. Economic Retrospective Voting in American National Elections : a Micro-Analysis. American Journal of Political Science, Madison, v. 22, n. 2.

GRAMSCI, A. 1968. Maquiavel, a política e o Estado moderno. Rio de Janeiro : Civilização Brasileira.

GRAZIANO, L. 1973. Patron-Client Relationships in Southern Italy. European Journal of Political Research, v. 1.

GRECO, G. 1972. Apunti per una Tipologia della Clientela. Quaderni di sociologia, Torino, n. 2, p. 178-197.

HOBSBAWM, E. 1978. Os camponeses e a política. Ensaios de opinião, Rio de Janeiro, v. 8 , p. $42-56$.

IRELAND, T. 1973. Discussion : Micropolitics and Macroeconomics. The American Economic Review, v. 63, n 2.

JOBERT, B. 1983. Clientélisme, Patronage et Participation Populaire. Revue Tiers Monde, Paris, t. XXIV, n. 95, p. 535-556.

KERBAUY, M. T. M. 1992. A morte do coronéis : política interiorana e poder local. São Paulo. Tese (Doutorado em Ciência Política). Pontifícia Universidade Católica de São Paulo.

KERNELL, S. 1977. Presidential Popularity and Negative Voting : an Alternative Explanation of the Midterm Congressional Decline of the President's Party. The American Political
Science Review, Washington D. C., v. 71, n. 1, p. 44-66.

LABROUSSE, E. 1970. En Survol sur l'Ouvrage. In : BRAUDEL, F. \& LABROUSSE, E. (orgs.). Histoire Économique et Sociale de la France. T. II. Paris : PUF.

LEAL, V. N. 1986. Coronelismo, Enxada e Voto. $5^{\text {a }}$ ed. São Paulo : Alfa-Ômega.

LEMARCHAND, R. 1981. Comparative Political Clientelism : Structure, Process and Optic. In : EINSENSTADT, S. \& LEMARCHAND, R. (orgs.). Political Clientelism, Patronage and Development. Beverly Hills : Sage.

MARTINS, P. H. N. 1991. La Recupération du "Developpement" par l'Oligarchie dans le Nordeste Brésilien ou la Modernisation Agraire Détournée. Revue Tiers Monde, Paris, v. 22, n. 126, p. 391-412.

MEDICI, A. 1995. Políticas sociais e federalismo. In : SILVA, P. \& AFFONSO, R. (orgs.). A federação em perspectiva : ensaios selecionados. São Paulo : FUNDAP.

NASCIMENTO, F. A. 1994. Avaliação do sistema municipal de governo. Relatório de Pesquisa. Teresina : SEPLAN/IIC.

NEVERS, J.-Y. 1983. Du Clientélisme à la Technocratie : Cent Ans de Démocratie Communale dans une Grande Ville, Toulouse. Revue Française de Science Politique, Paris, v. 33, n. 3, p. 428-454.

NUNES, E. 1997. A gramática política do Brasil. Brasília/Rio de Janeiro : ENAP/Jorge Zahar.

OLIVEIRA, F. 1972. A economia brasileira : crítica à razão dualista. Estudos do CEBRAP, São Paulo, n. 2, p. 3-82.

POULANTZAS, N. 1986. Poder político e classes sociais. Rio de Janeiro : Martins Fontes.

PRETECEILLE, E. 1986. Dynamiques Politiques Locales et Tendances Nationales. Espaces et Sociétés, Toulouse, n. 48-49.

REGO, R. M. 1993. Dilemas da questão agrária brasileira. São Paulo em perspectiva, v. 7, n. 3, p. 21-29.

REGO, W. D. L. 1996. Questões sobre a noção de via prussiana. In : ANTUNES, R. \& REGO, W. L. (orgs.). Lukács, um Galileu no século 
$X X$. São Paulo : Boitempo.

REZENDE, F. 1995. O financiamento das políticas públicas : problemas atuais. In : SILVA, P. L. B. \& AFFONSO, R. B. (orgs.). A federação em perspectiva : ensaios selecionados. São Paulo : FUNDAP.

ROLNIK, R. 1994. O que é cidade. São Paulo : Brasiliense.

RONIGER, L. 1994. Civil Society, Patronage and Democracy. International Journal of Comparative Sociology, Ontário, v. 35, n. 34, p. 207-220.

ROUQUIÉ, A. (1978). L'Analyse des Elections non Concorrentielles : Controle Clienteliste et Situations Autoritaires. In : HERMET (org.). Des Elections par comme les Autres. Paris : Fondation Nationale des Sciences Politiques.

SAES, D. 1987. Democracia. São Paulo : Ática. 1994. Estado e democracia : ensaios teóricos. Coleção Trajetória, n. 1. Campinas : IFCH-UNICAMP.

SCHUMPETER, J. A. 1981. Capitalismo, socialismo e democracia. Rio de Janeiro : Zahar.

SCOTT, J. C. 1971. Corrupção eleitoral. O aparecimento das máquinas políticas. Revista de Ciência Política, Rio de Janeiro, v. 5, n. 3, p. 37-73.
SINGER, P. 1965. A política das classes dominantes. In : IANNI, O. (org.). Política e revolução social no Brasil. Rio de Janeiro : Civilização Brasileira.

TELAROLLI, R. 1982. Eleições e fraudes eleitorais na República Velha. São Paulo: Brasiliense.

THEOBALD, R. 1983. The Decline of PatronClient Relations in Developed Societies. Archives Européennes de Sociologie, Cambridge, v. XXIV, n. 1, p. 136-147.

1992. On the Survival of Patronage in Developed Societies. Archives Européennes de Sociologie, Cambridge, v. XXXIII, n. 1, p. 183-191.

THERBORN, G. 1977. The Rule of Capital and The Rise of Democracy. New Left Review, London, n. 103, p. 3-41.

WEARTHFORD，M. S. 1978. Economic Conditions and Electoral Outcomes : Class Differences in the Political Responses to Recession. American Journal of Political Science, Madison, v. 22, n. 4.

WHITELY, P. \& SEYD, P. 1996. Rationality and Party Activism : Encompassing Tests of Alternative Models of Political Participation. European Journal of Political Research, Madison, n. 29, p. 215-234.

\section{OUTRAS FONTES}

Entrevistas com trabalhadores rurais, cabos eleitorais, políticos locais, realizadas pelo autor, em maio-jun. 1996. 